\title{
Desain Game "Agent J" dengan Memanfaatkan Mind Wave dan Webcam sebagai Kontrol Masukan dan Interaksi
}

\author{
Iwan Sonjaya, A mri Hidayatulloh, Mauldy Laya \\ Jurusan Teknik Informatika dan Komputer \\ Politeknik Negeri Jakarta \\ iwan.sonjaya@tik.pnj.ac.id, a mri.hidayatulloh@gmail.com, mauldy.laya@tik.pnj.ac.id
}

Diterima: 19 September 2016. Disetujui: 25 Oktober 2016. Dipublikasikan: Nope mber 2016

\begin{abstract}
Abstrak - Berbagai perangkat masukan kontrol telah dikembangkan, seperti Joystick, Pad, Wheelsteer, Keyboard bahkan Kinect. Jenis-jenis perangkat masukan yang ada, mengacu pada gerak motorik pemain. Hal ini masih membatasi para penyandang disabilitas untuk ikut bermain. Penerapan teknologi EEG pada Mindwave dan kamera web mampu diterapkan sebagai masukan kontrol permainan maya yang bersifat "Motionless". Permainan (game) ini menggunakan karakter dan environment tiga dimensi (3D) dengan 3 level/stage. Pengujian terhadap BetaUser mencapai keberhasilan rata - rata $\mathbf{7 8 . 8 \%}$ dengan sentimen ketertarikan sebesar $90 \%$, kesulitan sebesar $68 \%$, akurasi sebesar $72 \%$, imersifitas sebesar $78 \%$ dan objektifitas manfaat $86 \%$. Dari hasil pengujian dapat disimpulkan bahwa penerapan teknologi EEG telah mempengaruhi ketertarikan pemain dalam bermain dengan tingkat imersifitas dan manfaat yang cukup tinggi untuk kendali yang bersifat "Motionless" dimana hal ini dapat dikembangkan dan diterapkan bagi para penyandang disabilitas.
\end{abstract}

Kata Kunci : permainan, masukan kontrol, eeg, mindwave, 3d, game level

\section{PENDAHULUAN}

Perkembangan permainan maya atau disebut virtual game tidak terlepas dari perkembangan perangkat kontrol masukan. Kini berbagai macam perangkat/ kontrol masukan telah dikembangkan, seperti Joystick, Pad, Wheelsteer bahkan Kinect. Perangkat-perangkat masukan yang ada tidak terlepas dari kendali motorik pemain, dimana pemain diharuskan secara menyeluruh atau sebagian mengendalikan permainan dengan gerakan fisik. Dalam beberapa kondisi, jenis kontrol masukan tersebut akan terbentur oleh keterbatas gerak pemain[1].

Analisis aktifitas otak atau disebut dengan EEG (Elektroenselofalogram) digunakan dalam dunia medis sebagai salah satu cara untuk mendeteksi kelainan pada otak manusia dan beberapa penyakit yang berhubungan dengan mental. Kini dengan ketersediaan alat Mindwave telah membuka luas penerapan analisis EEG di berbagai bidang, termasuk pengembangan BCI (Brain Computer Interface)[1].

Penggunaan Mindwave sudah masuk dalam tahap pengembangan permainan sebagai alat kendali atau kontrol antarmuka. Meskipun penerapan Mindwave pada permainan terlihat begitu menjanjikan, masih ada beberapa kendala yang belum dapat dipecahkan seperti keunikan cara berfikir manusia membuat penerapan Mindwave saja sebagai kendali kontrol permainan menjadi lebih sulit. Penerapan dari teknologi Mindwave dilihat sebagai jalan untuk membuka teknologi baru dalam kendali masukan kontrol permainan bagi para penderita disabilitas. Analisis EEG dapat diterapkan untuk mengambil keputusan berdasarkan kondisi pikiran pemain seperti konsentrasi, sehingga teknologi tersebut dapat dimanfaatkan secara maksimal dalam kendali masukan kontrol permainan[2].

Penelitian ini bertujuan membuat game dengan menggunakan perangkat Mindwave dan webcam sebagai perangkat masukan untuk mengontrol interaksi antarmuka permainan. Penelitian ini dapat menjadi salah satu jalan untuk membuka kesempatan bagi para pemain terlebih lagi para penyandang disabilitas untuk ikut merasakan pengalaman bermain permainan virtual.

\section{TINJAUAN PUSTAKA}

\section{A. Permainan Maya (Virtual Game)}

Permainan maya atau Virtual Game adalah sebuah permainan elektronik yang melibatkan interaksi pengguna dan antarmuka permainan untuk menciptakan sebuah visual dari permainan di perangkat elektronik[3]. Permainan maya pada umu mnya ditampilkan dalam perangkat visual raster (pixel) seperti layar komputer yang dapat 
menampilkan gambar dua dimensi maupun tiga dimensi. Sistem elektronik yang digunakan untuk permainan dapat dikatakan sebagai platform seperti personal ko mputer ataupun konsol. Permainan maya pada umumnya membutuhkan perangkat masukan seperti keyboard, mouse, stick, game pad atau lainnya. Permainan maya telah menjadi industri yang besar dan aspek bisnis yang cukup menjanjikan bagi para pelaku usaha permainan maya [4].

\section{B. Perangkat Masukan Kontrol}

Perangkat masukan kontrol atau dapat dibilang perangkat kendali adalah suatu perangkat atau alat yang digunakan oleh permainan untuk mendapatkan masukan dari pemain. Pada umunya masukan yang diterima dimanfaatkan untuk mengendalikan objek atau karakter dalam permainan. Biasannya perangkat masukan dihubungkan ke dalam konsol game menggunakan kabel ataupun bluetooth. Kini, terdapat banyak jenis perangkat masukan permainan yang dikembangkan dan telah digunakan dalam perkembangan industri permainan maya [5].

\section{Elektroensefalogram (EEG)}

Elektroensefalogram (EEG) adalah rekaman aktifitas listrik otak yang digunakan untuk mendiagnosis kondisi neurologis seperti gangguan kejang (Epilepsi). Tes elektroensefalografi dilakukan dengan menyisipkan elektroda lempengan logam di kulit kepala. Selain itu EEG digunakan untuk mengukur fungsi dari otak dari waktu ke waktu[6].

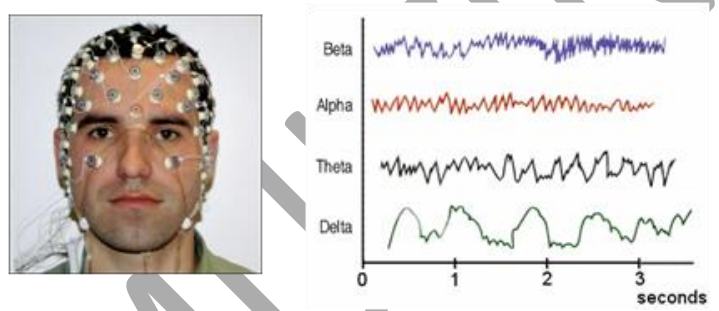

Gambar 1. Elektmensefalogram (EEG)

Selain digunakan untuk mendeteksi kelainan mental pada pasien, EEG juga digunakan untuk menunjukan lokasi aktifitas otak pada saat kejang dan juga dapat mendeteksi kerusakan pada otak. EEG juga dapat digunakan untuk menetapkan apabila seseorang sudah mati atau tidak dari aktifitas otak yang di rekam, sehingga dapat diputuskan apabila seseorang masih memerlukan Life-Support Equipment atau tidak [5].

\section{Perangkat Mindwave}

Perangkat Mindwave adalah sebuah perangkat Elektroensefalograf yang bersifat portable. Mindwave adalah salah satu produk dari
NeuroSky, Inc. yang dikembangkan sebagai perangkat Brain-Computer Interface (BCI) untuk consumer umum. Penge mbangan Mindwave dimulai pada tahun 2004 dan terus berkembang hingga saat ini. Pada umumnya Mindwave digunakan sebagai perangkat pendukung pada aplikasi hiburan, pendidikan atau kesehatan[7].

\section{METODE PENELITIAN}

Metode Penelitian yang digunakan adalah dengan menggunakan metode pengembangan multimed ia Luther, dengan tahap-tahap berikut :

1. Konsep, yaitu menentukan tujuan dan siapa saja pengguna permainan (identifikasi pengguna), tujuan permainan (hiburan, pelatihan, dan lain lain), dan spesifikasi u mu m.

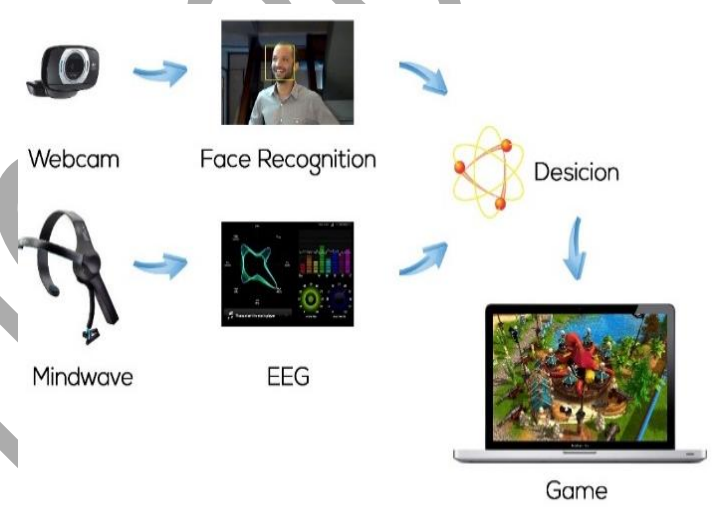

Gambar 2. Konsep dan Sistem Game

2. Desain, yaitu tahap membuat spesifikasi secara rinci mengenai arsitektur program, gaya, tampilan dan kebutuhan material atau bahan untuk permainan. Dalam hal ini membuat environment dan karakter, Setting tiap-tiap stage/level dalam game.

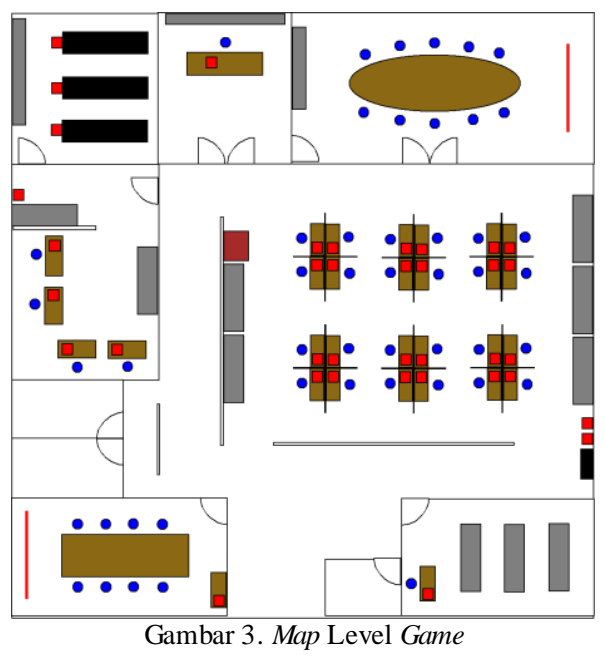


3. Pengumpulan Material (Material Collecting), yaitu tahap pengumpulan bahan yang sesuai dengan kebutuhan yang dikerjakan. Aset-aset game yang kan digunakan, antara lain gambar clip art, foto, animasi, video, dan audio.

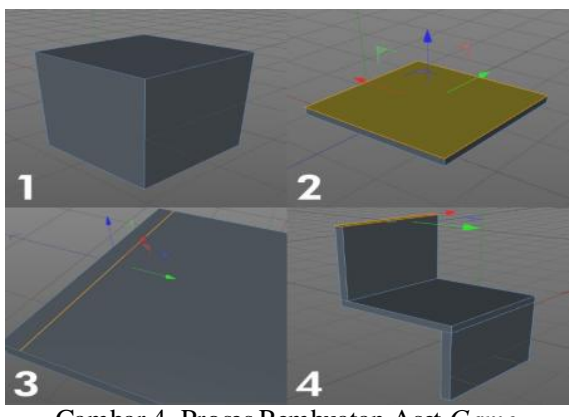

Gambar 4. Proses Pembuatan Aset Game

4. Penggabungan (Assembly), tahap pembuatan semua objek atau bahan multimedia, pemrograman game, penentuan kontrol masukan, dan interaksi gameplay.

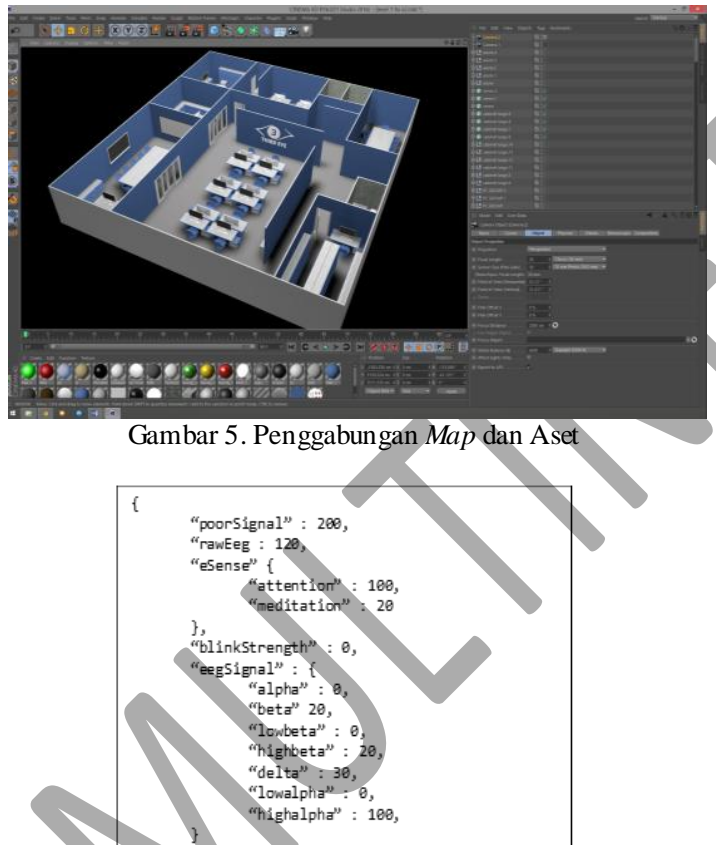

Gambar 6. Pemrograman Game dengan Kontrol Masukan dari Mindwave

5. Pengujian (Testing), yaitu tahap pengujian dilakukan setelah menyelesaikan tahap assembly dengan menjalankan permainan dan dilihat apakah ada kesalahan atau tidak. Tahap pertama pada tahap ini disebut juga sebagai tahap pengujian alfa (alpha test) yang pengujiannya dilakukan oleh pembuatnya sendiri. Setelah lolos dari pengujian alfa, pengujian beta yang melibatkan pengguna akhir (end user) akan dilakukan.
6. Distribusi, yaitu tahap akhir pengemasan dan penyebaran dari produk. Tahap ini juga disebut sebagai tahap evaluasi untuk pengembangan produk yang telah jadi supaya menjadi lebih baik lagi.

\section{HASIL DAN PEMBAHASAN}

Setelah proses material collecting dan assembly dilakukan sehingga aset-aset game sudah digabungkan dan user interface game telah dibuat seperti Gambar 7.
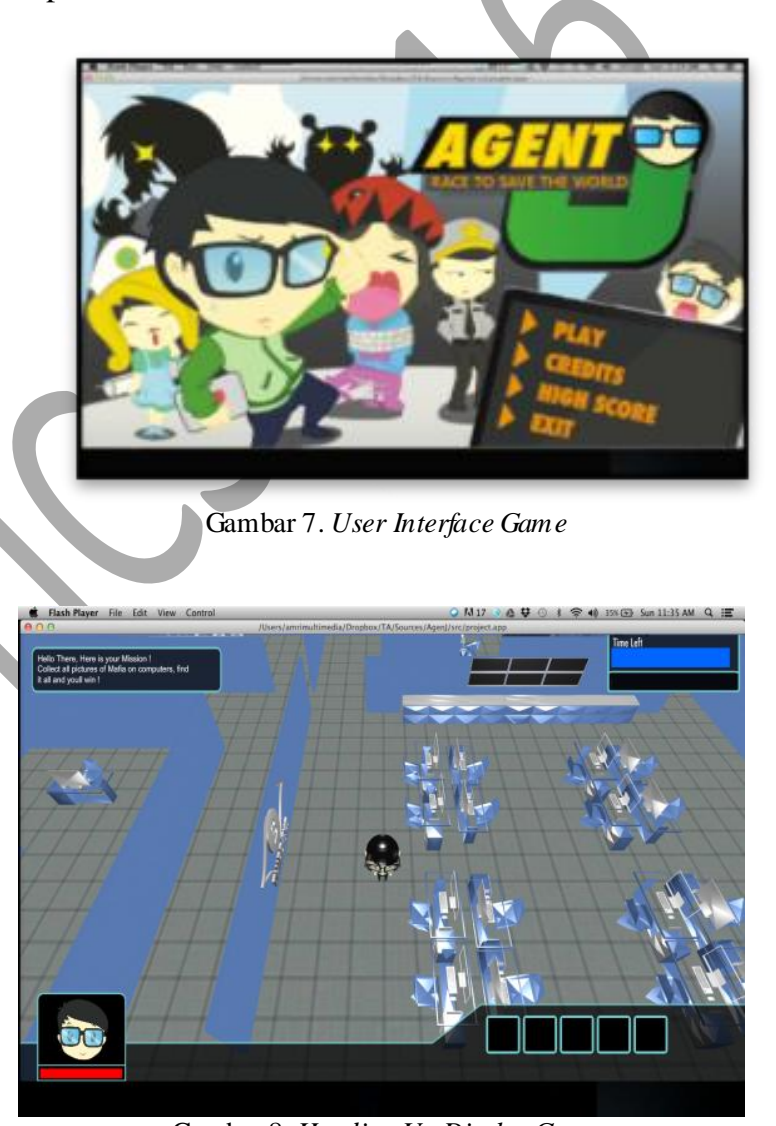

Gambar 8. Heading Up Display Game

Analisis masukan mindwave digunakan untuk menggerakkan karakter pada saat permainan berlangsung. Alur proses yang diterapkan dapat dilihat pada blok diagram berikut.

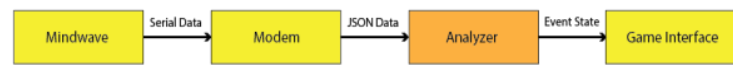

Gambar 9. Blok Diagram Komunikasi Data Mindwave

Sesuai dengan Gambar 9, perangkat mindwave mengirimkan rentetan serial data melalu koneksi bluetooth ke modem (Modulation Demodulation) dimana modem akan mengakuisisi sinyal data ini ke dalam format JSON. Modem meneruskan data ke Analyzer. Di dalam analyzer ini 
data JSON akan dianalisis dan dikirimkan ke Game Interface sebagai Event State. Event state akan diterjemahkan oleh Game Interface untuk mengambil keputusan, seperti menggerakan karakter objek, atau melakukan klik pada tombol dalam permainan. Untuk lebih jelas dari alur proses yang ada, Gambar 11 adalah Activity Diagram dari proses ko munikasi data.

Ko munikasi antara perangkat mindwave dan juga modem terjadi melalui koneksi Bluetooth, dimana data serial terdiri dari sederetan angkaangka sepanjang 512 bit yang telah dienkripsi oleh perangkat mindwave dan didekripsi oleh perangkat modem. Modem mengakuisisi serial data menjadi format JSON. Data JSON yang ditangkap oleh modul analyzer didekode menjadi objek yang dikenali oleh Actionscript menggunakan pustaka JSON Parser[8]. Nilai dari eSense > Attention di proses sebagai nilai gamma (fokus dan konsentrasi), jika nilai diatas 20 maka game interface akan menggerakkan objek dalam permainan.

$$
f(\text { move })=\left\{\begin{aligned}
\text { true }, & \text { attention }>20 \\
\text { false }, & \text { otherwise }
\end{aligned}\right.
$$

Sama halnya dengan objek BlinkStrength dimana nilai blinkstrength (kedipan) akan dibaca jika nilai diatas 80 (maksimum 100) maka akan melakukan trigger klik.

$$
\boldsymbol{f}(\text { click })=\left\{\begin{aligned}
\text { true }, & \text { blinkStrengt } h>80 \\
\text { false }, & \text { otherwise }
\end{aligned}\right.
$$

Selain menggunakan mindwave sebagai masukan kontrol permainan, digunakan juga kamera web. Kamera web bertugas untuk menangkap citra wajah pemain, dengan memanfaatkan teknologi Computer Vision (CV) untuk mengenali dan menangkap arah pergerakan wajah menjadikan kamera web salah satu perangkat pendukung permainan untuk menentukan arah gerak karakter dalam permainan. Berikut adalah alur proses penerapan kamera web sebagai masukan kontrol dalamblok diagram.

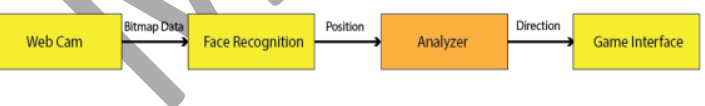

Gambar 10. Blok Diagram Komunikasi Data Webcam

Blok diagram pada Gambar 10 menjelaskan alur proses komunikasi antara perangkat kamera web hingga game interface. Kamera web menangkap sederetan citra dan mengubahnya menjadi Bitmap Data. Bitmap data diproses oleh pustaka Face Recognition untuk mengenali wajah dan posisi wajah tersebut.

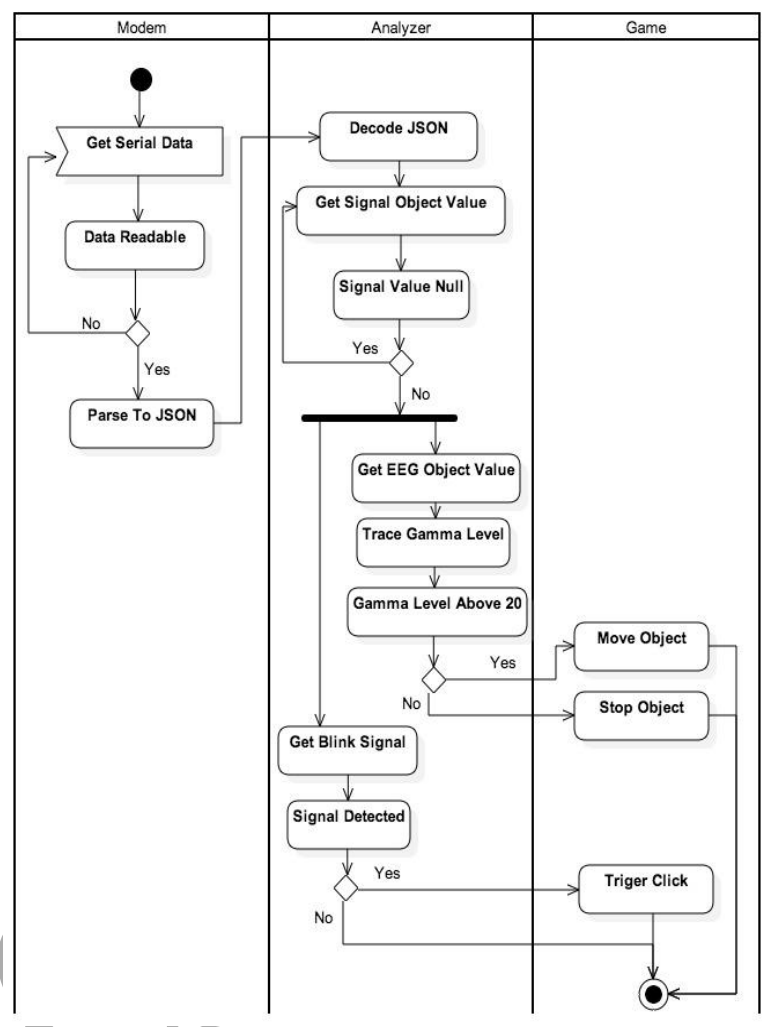

Gambar 11. Diagram Aktifit as Komunikasi Data Mindwave

Jika terdeteksi, maka modul ini akan langsung mengirim data posisi wajah yang berupa posisi X, posisi Y, lebar (width) dan tinggi (height) wajah ke modul Analyzer. Modul Analyzer memp roses rentetan posisi yang dikirim oleh modul sebelumnya menjadi sampling data yang digunakan untuk membaca atau melacak pergerakan wajah. Setelah mendapatkan posisi pergerakan atau arah pergerakan, modul Analyzer akan mengirimkannya ke Game Interface untuk keputusan pada antarmuka permainan. Berikut adalah alur proses lebih detail dalam Activity Diagram.

Pada Gambar 12, diperlihatkan alur proses lebih mendetail face recognition, analyzer dan juga game interface. Face Recognition akan menerima rentetan bitmap data dan mendeteksi jika terdapat wajah dalam bitmap data. Jika ditemukan maka analyzer akan menyimpan data posisi sebagai sampling data. Nilai-nilai yang dapat dideteksi diberikan ke modul analyzer untuk dianalisis. Dimana nilai-nilai yang didapatkan dari pustaka face recognition, dimana :

- $\mathrm{X}=$ Posisi wajah pada sumbu $\mathrm{X}$

- $\mathrm{Y}=$ Posisi wajah pada sumbu Y

- $\mathrm{w}=$ Lebar wajah yang terdeteksi

- $\mathrm{h}=$ Tinggi wajah yang terdeteksi

- $\mathrm{s}=$ Scalar (Faktor Pengali) 


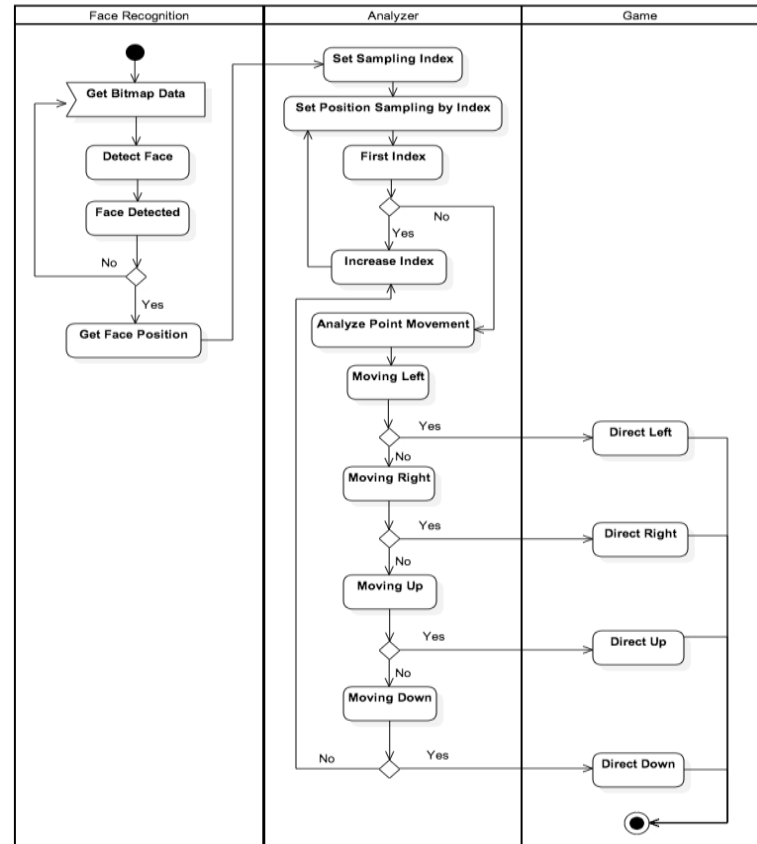

Gambar 12. Diagram Aktifitas Komunikasi Data Webcam

Dapat dilihat bahwa terdapat variabel $\mathbf{s}$ sebagai scalar (faktor pengali). Sehingga seluruh nilai dari $\mathrm{X}, \mathrm{Y}, \mathrm{w}, \mathrm{h}$ harus di kalikan terlebih dahulu dengan s untuk mendapatkan posisi wajah, lebar dan tinggi wajah. Yaitu dapat dilihat dari persamaan(1)(4) berikut:

$$
\begin{aligned}
& X=X \cdot s \\
& Y=Y \cdot s \\
& w=w \cdot s \\
& h=h \cdot s
\end{aligned}
$$

Setelah mendapatkan nilai asli dari $\mathrm{X}, \mathrm{Y}, \mathrm{h}, \mathrm{w}$ langkah berikutnya adalah menentukan center position dari wajah, dapat dilihat dari persamaan (5) dan (6) be rikut:

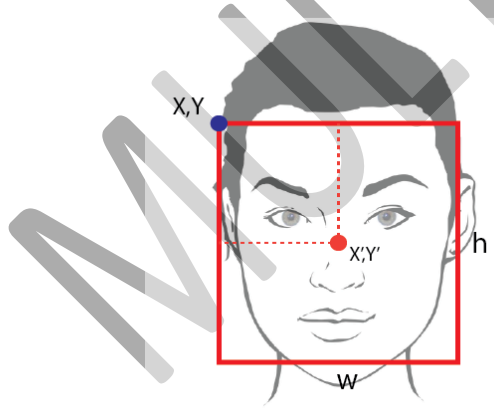

Gambar 13. Penentuan Center Position dariWajah

$$
\begin{aligned}
& X^{\prime}=X+\left(\frac{1}{2} \cdot w\right) \\
& Y^{\prime}=Y+\left(\frac{1}{2} \cdot h\right)
\end{aligned}
$$

Nilai dari $X^{\prime}$ dan $Y^{\prime}$ disimpan sebagai nilai vector sampling dalam data Array pada periode $\mathrm{t}$ selama pergerakan wajah terjadi. Data array membentuk titik-titik resultan dari pergerakan wajah, dapat dilihat pada Gambar 14.

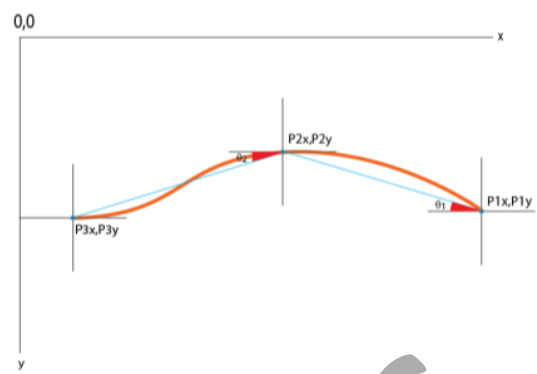

Gambar 14. Grafik Titik Result an dariPergerakan Wajah

$$
P=\left[\begin{array}{ccc}
X 1 & \cdots & X n \\
Y 1 & \cdots & Y n
\end{array}\right] \quad P \in \mathbb{R}
$$

Setelah mendapat titik-titik resultan in i, tahap selanjutnya dalam menganalis is pergerakan adalah menemukan sudut theta yaitu sudut antar dua titik terhadap sumbu X. Proses analisis pergerakan dilakukan satu persatu antara satu titik ke titik selanjutnya sehingga dapat ditetapkan arah pergerakan tiap titik atau point dengan menggunakan persamaan (7) - (10).

$$
\begin{aligned}
& P 1 x=P X(n-1) \\
& P 1 y=P Y(n-1) \\
& P 2 x=P X n \\
& P 2 y=P Y n
\end{aligned}
$$

Tahapan berikutnya adalah menghitung sudut theta, dapat dilihat pada persamaan berikut

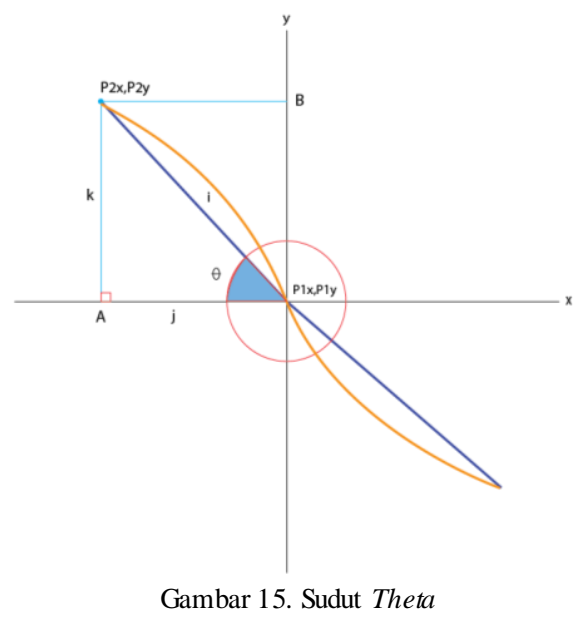

Dimana posisi dari titik A dan titik B dapat diketahui dari sumbu sejajar dari P1 dan P2, yaitu sebagai berikut

$$
\begin{aligned}
& A x=P 2 x \\
& A y=P 1 y \\
& B x=P 1 x \\
& B y=P 2 y
\end{aligned}
$$


Setelah mengetahui posisi dari titik A dan B maka dapat tentukan pula panjang dari garis $\mathrm{k}$ dan $\mathrm{j}$ dengan menggunakan persamaan (15) dan (16).

$$
\begin{aligned}
k & =\Delta(A y)(P 2 y) \\
j & =\Delta(B x)(P 2 x) \\
& \equiv \Delta(A x)(P 1 x)
\end{aligned}
$$

Dengan menerapkan konsep Pythagoras, maka dapat diketahui bahwa nilai i adalah sebagai berikut

$$
\begin{aligned}
& i=\sqrt{k^{2}+j^{2}} \\
& \equiv i^{2}=k^{2}+j^{2}
\end{aligned}
$$

Untuk menghitung sudut theta, dapat digunakan aturan sinus pada trigonometri, pada segitiga sikusiku yang didapat dari tiga titik P1, P2 dan A maka dapat disimpulkan bahwa sudut theta adalah sebagai berikut.

$$
\begin{aligned}
& \sin \theta=\frac{k}{i} \\
& \operatorname{rad} \theta=\sin ^{-1}(\sin \theta) \\
& \angle \theta=\operatorname{rad} \theta \cdot \frac{180}{\pi}
\end{aligned}
$$

Setelah mendapatkan besaran sudut theta, langkah berikutnya adalah mengklasifikasikan besaran sudut dalam kuadran-kuadran berikut untuk diketahui arah pergerakan vector. Klasifikasi besaran sudut menjadi empat kuadran di bawah ini digunakan untuk menentukan arah pergerakan, berikut adalah klasifikasi pergerakan berdasarkan kuadran diatas.

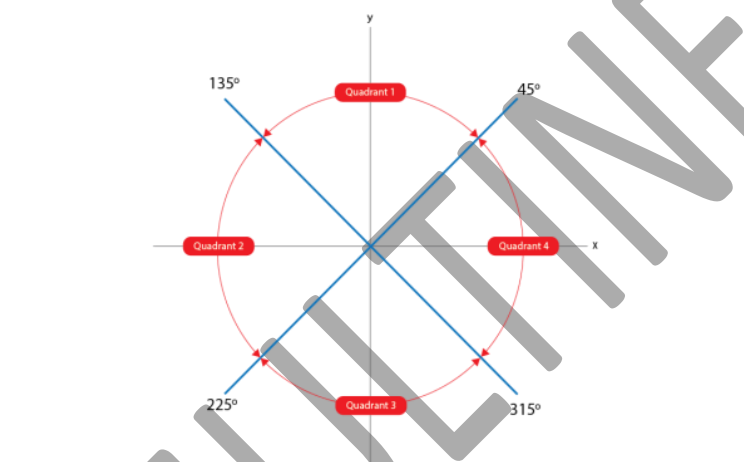

Gambar 16. Klasifikasi Pergerakan Wajah Berdasarkan Kuadran

$$
f(\theta)= \begin{cases}U P, & \theta \in \text { Quadrant } 1 \\ D O W N, & \theta \in \text { Quadrant } 3 \\ L E F T, & \theta \in \text { Quadrant } 4 \\ \text { RIGHT, } & \theta \in \text { Quadrant } 2\end{cases}
$$

Setelah selesai melakukan proses pembuatan game, kemudian dilakukan tahap pengujian sebagai pertimbangan dan percobaan produk kepada khalayak u mu m.

Pengujian dibagi menjadi dua bagian. Bagian pertama adalah pengujian teknis terhadap masukan kontrol untuk mengetahui persentasi keberhasilan dari penerapan algoritma dan tingkat akurasi terhadap penanggapan masukan kontrol. Bagian kedua, pengujian non-teknis, yaitu melibatkan para beta tester dalam menguji permainan dan tingkat sentimen pemain terahadap permainan itu sendiri, baik dari sisi ketertarikan pemain dan juga dari sisi kepuasan pemain terhadap masukan kontrol dan interaksi permainan. Responden pengujian yang dilakukan merupakan mahasiswa aktif Politeknik Negeri Jakarta.

Berikut adalah hasil pengujian teknis terhadap penerapan masukan kontrol dari kamera

\begin{tabular}{|c|c|}
\hline Detik Ke-n & Tingkat Keberhasilan \\
\hline 1 & 2.6 \\
\hline 2 & 35.2 \\
\hline 3 & 62 \\
\hline 4 & 74 \\
\hline 5 & 72 \\
\hline
\end{tabular}
web.

TABEL 1. HASIL PERCOBAAN MASUKAN CONT ROL DARI WEBCAM

\begin{tabular}{|c|c|}
\hline Percobaan Ke- $\boldsymbol{n}$ & Tingkat Ke berhasilan \\
\hline Percobaan ke 1 & $100 \%$ \\
\hline Percobaan ke 2 & $75 \%$ \\
\hline Percobaan ke 3 & $75 \%$ \\
\hline Percobaan ke 4 & $75 \%$ \\
\hline Percobaan ke 5 & $100 \%$ \\
\hline Rata-rata & $85 \%$ \\
\hline
\end{tabular}

Dari Tabel 1 dapat disimpulkan bahwa tingkat keberhasilan dari masukan kontrol Kamera Web $85 \%$. Berikut adalah kesuluruhan data dari percobaan konsentrasi pada mindwave. Dari hasil data pengujian sebanyak 5 kali pengujian sela ma 5 detik dapat dilihat rata-rata setiap rekaman aktifitas Beta di tiap detik seperti pada Tabel 2.

Berikut adalah selisih jarak pergerakan nilai konsentrasi dari detik $n$ hingga detik $n+1$ dalam Tabel 3 .

TABEL 3. SELISIH JARAK PERGERAKAN NILAI KONSENTRASI

\begin{tabular}{|c|c|}
\hline Detik $\boldsymbol{n}-\boldsymbol{n}+\boldsymbol{I}$ & Tingk at Ke berh asilan \\
\hline 1 & 2.6 \\
\hline 2 & 32.6 \\
\hline 3 & 26.8 \\
\hline 4 & 12 \\
\hline 5 & -4 \\
\hline Rata - Rata & 14 \\
\hline
\end{tabular}

Dari Tabel 3 dapat disimpulkan bahwa tingkat akselerasi perubahan nilai adalah 14 nilai / detik, sehingga dibutuhkan minimal waktu selama 2 detik untuk menggerakan karakter.

Pengujian non-teknis melibatkan 15 beta tester yang diambil secara acak. Penguji beta diminta untuk memainkan permainan sebanyak empat kali dan setelah bermain penguji diminta untuk mengisi kuisioner, hasil dari kuisioner digunakan untuk hasil analisis tingkat keberhasilan pemain dengan kontrol masukan dan interaksi. 
Dalam pengujian ini terdapat lima pertanyaan yang diajukan kepada penguji beta sebagai indikator penilaian, yaitu sebagai berikut:

\section{TABEL 4. DAFTAR PERTANYAAN KUISIONER}

\begin{tabular}{|c|l|}
\hline $\mathbf{Q}_{\mathbf{1}}$ & $\begin{array}{l}\text { Pada skala 1 sampai 5, seberapa menarikah menurut anda } \\
\text { tent ang penggunaan Mindwave dan } \mathrm{CV} * * \text { sebagai } \\
\text { masukan Kontrol permainan? }\end{array}$ \\
\hline $\mathbf{Q}_{\mathbf{2}}$ & $\begin{array}{l}\text { Pada skala 1 sampai 5, seberapa sulitkah anda mengontrol } \\
\text { permainan hanya dengan menggunakan Mindwave dan } \\
\mathrm{CV} * \text { ? }\end{array}$ \\
\hline $\mathbf{Q}_{\mathbf{3}}$ & $\begin{array}{l}\text { Pada skala 1 sampai 5, seberapa efekt ifkah / tinggi akurasi } \\
\text { masukan control Mindwave dan CV** pada permainan } \\
\text { Agent J? }\end{array}$ \\
\hline $\mathbf{Q}_{\mathbf{4}}$ & $\begin{array}{l}\text { Pada skala 1 sampai 5, seberapa tinggikah interaksi yang } \\
\text { terjadi ant ara permainan dengan anda (apakah anda } \\
\text { merasa interaksi yang sangat mendalam dengan } \\
\text { permainan) pada permainan Agent J? }\end{array}$ \\
\hline $\mathbf{Q}_{\mathbf{5}}$ & $\begin{array}{l}\text { Pada skala 1 sampai 5, seberapa bermanfaatkah } \\
\text { pengembangan kontrol permainan dengan Mindwave dan } \\
\text { CV (Computer Vision) terhadap masy arakat umum? }\end{array}$ \\
\hline
\end{tabular}

Berikut adalah representasi grafik dari hasil persentase di setiap pertanyaan.

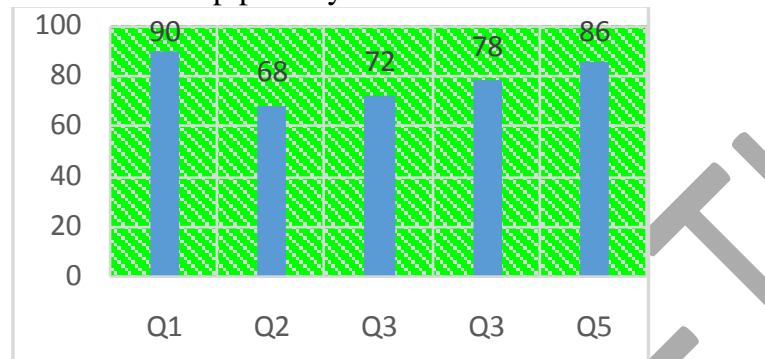

Gambar 17. Grafik Persent ase Hasil Kuisioner

Dari hasil perhitungan pada Gambar 17 dapat dilihat bahwa tiap aspek dari pertanyaan dapat disimpulkan sebagai berikut.

1. Sebanyak $90 \%$ dari penguji beta menyatakan tertarik dengan penerapan masukan kontrol permainan menggunakan Mindwave dan kamera web.

2. Sebanyak $68 \%$ dari penguji beta menyatakan sulit untuk mengendalikan permainan hanya dengan menggunakan Mindwave dan kamera web.

3. Sebanyak $72 \%$ dari penguji beta menyatakan kendali masukan menggunakan Mindwave dan kamera web a kurat.

4. Sebanyak $78 \%$ dari penguji beta menyatakan tingginya tingkat imersifitas interaksi antar pemain.

5. Sebanyak $86 \%$ dari penguji beta menyatakan tingginya manfaat penerapan dari masukan kontrol permainan menggunakan Mindwave dan kamera web.

\section{KESIMPULAN}

Dalam menyelesaikan penelitian ini penulis mengambil beberapa kesimpulan bahwa penerapan masukan kendali Mindwave dan kamera web dalam permainan bersifat lebih "Motionless" atau tidak banyak pergerakan pada pemain dibanding penerapan kontrol pemainan pada umumnya. Walaupun bersifat motionless penerapan kendali ini masih diasumsikan sulit dengan nilai sentimen persentase kesulitan sebesar $68 \%$ dan juga akurasi hanya $72 \%$.

Penerapan interaksi antarmuka game sangat menarik, karena desain interface yang dikembangkan untuk aplikasi visual dan animasi, ditinjau dari respon pengguna terhadap kepuasan interaksi antarmuka cukup tinggi, dengan persentase sebesar $90 \%$.

\section{REFERENSI}

[1] N Yildirim, A Varol, 2013: Developing educat ional game software which measures attention and meditation with brainwaves: matching mind math - ICEE ICIT 2013 Conference.

[2] Vrocher, Diamond MD, 2009: How useful is EEG and EEG monitoring in the acutely ill and how to interpret it?." Epilepsia 50.s12 (2009): 34-37.

[3] Kim Gerard J, 2014 : Human-Computer Interaction, Fundamental and Practice. Broken Sound Parkway NW : CRC Press.

[4] Salen, Katie. 2003. Rules of Play - Game Design Fundamental. Cambridge, Massachusetts : MIT Press.

[5] William Lu, 2008: Evolution of Video Game Controllers. Roseville: Prima Publishing.

[6] D. Y. Qiao et al., 2013: "A Portable Mind Wave Monit or Headrest Applied in Sleep Promotion", Applied Mechanics and Materials, Vols. 411-414, pp. 1475-1479.

[7] Birg Daniel, 2012 : NeuroSky Mindwave Mobile Review. 20 Juni 2015. http://www.laptopmag.com/reviews /accessories/neurosky-mindwave-mobile.

[8] Grossmanm, Gary, 2006: ActionScript 3.0 Design Patterns: Object Oriented Programming Techniques. O'Reilly Media, Inc. 